Pustaka Karya: Jurnal Ilmiah Ilmu Perpustakaan dan Informasi Vol. 8 No. 2, Desember 2020, Hal. 95-107 http://dx.doi.org/10.18592/pk.v8i2.5135 ISSN (p) : 2089-5216 | ISSN (e) : 2723-7699

\title{
Kompetensi pustakawan di perpustakaan madrasah aliyah dan tsanawiyah negeri se-Kota Banjarmasin Kalimantan Selatan ${ }^{1}$ Laila Rahmawati, ${ }^{2}$ Juairiah, ${ }^{3}$ Siti Wahdah \\ ${ }^{123}$ Dosen Program Studi Ilmu Perpustakaan dan Informasi Islam, UIN Antasari Banjarmasin \\ ${ }^{123}$ Jalan A. Yani KM. 4,5, Kota Banjarmasin, Kalimantan Selatan 70235 e-mail:1ailarahmawati72@gmail.com, ${ }^{2}$ juairiah.efendi@gmail.com, ${ }^{3}$ wahdahsiti01@gmail.com
}

\begin{abstract}
This study aims to determine how far the competence of school/madrasah librarians in the city of Banjarmasin. This type of qualitative research uses a qualitative approach. The research subjects were school librarians in the city of Banjarmasin (MAN 2 Model, MTsN Pemurus Dalam, MTsN 1 Pekauman, MTsN 3 Mulawarman and MAN 3 Mulawarman). The object of research is the competence of school librarians. Data collection techniques using the method of observation, interviews and documentation. Data analysis techniques using data reduction, data presentation, triangulation, drawing conclusions. Thoose are: 1) the managerial competence of librarians still focuses on administrative evaluation, 2) the information management competence of librarians has not been fully able to meet the expectations of information management competence, 3) the educational competence must improve competence literacy, 4) the personality competence has not have professional awareness, 5) the social competence of librarians is still not paying attention to the development of personal character in the pattern of relationships with users, 6) the competence of professional development of librarians has not been able to describe adequate competencies, especially in the form of scientific works or scientific publications. Thoose are 3 main factors that can improve the competence of librarians, namely individual factors, school factors and the desire to attend education and seminars.
\end{abstract}

Keywords: competence; librarian; madrasah aliyah, madrasah tsanawiyah

\begin{abstract}
ABSTRAK
Penelitian ini bertujuan untuk mengetahui seberapa jauh kompetensi pustakawan sekolah/madrasah di lingkungan Kota Banjarmasin. Jenis penelitian kualitatif menggunakan pendekatan kualitatif. Subjek penelitian adalah pustakawan sekolah kota Banjarmasin (MAN 2 Model, MTsN Pemurus Dalam, MTsN 1 Pekauman, MTsN 3 Mulawarman dan MAN 3 Mulawarman). Objek penelitian adalah kompetensi pustakawan sekolah. Teknik pengumpulan data menggunakan metode observasi, wawancara dan dokumentasi. Teknik analisis data menggunakan reduksi data, penyajian data, triangulasi, penarikan kesimpulan. Bahwa: 1) pada kompetensi manajerial para pustakawan masih menitikberatkan evaluasi administratif, 2) pada kompetensi pengelolaan informasi para pustakawan belum sepenuhnya mampu memenuhi ekspektasi kompetensi pengelolaan informasi, 3) pada kompetensi kependidikan harus meningkatkan kompetensi literasi, 4) pada kompetensi kepribadian belum memiliki kesadaran professional, 5) pada kompetensi sosial pustakawan masih kurang memerhatikan pembangunan karakter pribadi dalam pola hubungan dengan pemustaka, 6) kompetensi pengembangan profesi pustakawan belum bisa menggambarkan kompetensi yang memadai, terutama dalam bentuk karya ilmiah atau publikasi ilmiah. Ada 3 faktor utama yang dapat meningkatkan kompetensi pustakawan yakni faktor individu, faktor sekolah dan faktor keinginan untuk mengikuti pendidikan dan seminar.
\end{abstract}

Kata Kunci: kompetensi; madrasah aliyah, madrasah tsanawiyah; pustakawan 


\section{PENDAHULUAN}

Salah satu sarana dalam menunjang proses belajar dan mengajar di sekolah adalah perpustakaan. Perpustakaan sekolah dewasa ini bukan hanya merupakan unit kerja yang menyediakan bacaan guna menambah pengetahuan dan wawasan bagi murid, tapi juga merupakan bagian yang integral pembelajaran. Artinya, penyelenggaraan perpustakaan sekolah harus sejalan dengan visi dan misi sekolah dengan mengadakan bahan bacaan bermutu yang sesuai kurikulum, menyelenggarakan kegiatan yang berkaitan dengan bidang studi, dan kegiatan penunjang lain, misalnya berkaitan dengan peristiwa penting yang diperingati di sekolah.

Dalam Undang-Undang Nomor 43 Tahun 2007 tentang perpustakaan disebutkan bahwa perpustakaan adalah institusi pengelola koleksi karya tulis, karya cetak, dan/atau karya rekam secara profesional dengan sistem yang baku guna memenuhi kebutuhan pendidikan, penelitian, pelestarian, informasi, dan rekreasi para pemustaka.

Perpustakaan sebagai salah satu lembaga / institusi merupakan salah satu wahana information resourch; knowledge resourch yang keberadaannya di harapkan mampu membantu pemerintah dalam mencerdaskan kehidupan bangsa. Bahwa semua kegiatan yang dilakukan selalu mengandung unsur / nilai pembelajaran, pengembangan iptek budaya maupun penunjang penelitian. Sebagai based of learning keberadaannya senantiasa di harapkan untuk dapat memenuhi harapan pemustaka dalam memperoleh informasi atau data yang dibutuhkan. Ketersediaan informasi semakin dituntut sejalan dengan keinginan masyarakat yang membutuhkannya. Kebutuhan masyarakat akan informasi yang cepat, akurat, tepat, mudah, murah dan spesifik inilah yang harus disikapi oleh para pustakawan maupun pengelola perpustakaan. Sikap yang harus ditunjukan adalah dengan menyediakan kebutuhan masyarakat sesuai dengan keinginannya.

Dengan membanjirnya informasi dalam skala global, perpustakaan sekolah diharapkan tidak hanya menyediakan buku bacaan saja namun juga perlu menyediakan sumber informasi lainnya, seperti bahan audio-visual dan multimedia, serta akses informasi ke internet. Akses ke internet ini diperlukan untuk menambah dan melengkapi pengetahuan anak dari sumber lain yang tidak dimiliki oleh perpustakaan di sekolah. Menyikapi hal ini tentunya untuk mengelola semua itu di perpustakaan memerlukan tenaga perpustakaan atau pustakawan yang mampu mengelola perpustakaan.

Pustakawan sekolah sebagaimana juga pustakawan di tempat lainnya, sebagai profesi menempati posisi dalam kategori profesi yang profesional, yang ditandai dengan dimilikinya kualifikasi keahlian di bidang perpustakaan atau kompetensi memadai yang dipersyaratkan di bidang perpustakaan baik itu kompetensi profesional maupun kompetensi personal. Kompetensi profesional dan personal tersebut sebagaimana yang disebutkan dalam Peraturan Menteri Pendidikan Nasional Nomor 25 Tahun 2008: kompetensi profesional berkaitan dengan kompetensi manajerial, kompetensi pengelolaan informasi, kompetensi kependidikan, dan pengembangan profesi; sedangkan kompetensi personal berkaitan dengan kompetensi kepribadian dan sosial.

Kompetensi adalah suatu hal yang sangat penting bagi profesi apa pun termasuk pustakawan sekolah. Apalagi dewasa ini, kompetensi menjadi persyaratan yang harus dipenuhi oleh sumber daya manusia. Masalah kompetensi menjadi penting, karena kompetensi menawarkan suatu kerangka kerja yang efektif dan efisien dalam mendayagunakan sumberdaya yang terbatas. Kompetensi dalam hal ini dapat menunjukkan integritas pribadi pustakawan terhadap profesi yang digelutinya. Kompetensi menjadi prasyarat mutlak setiap pustakawan dalam organisasi perpustakaan yang terukur dalam evaluasi kinerja, seperti halnya juga pustakawan sekolah pada Perpustakaan Madrasah Kota Banjarmasin. 
Perpustakaan madrasah adalah perpustakaan sekolah baik negeri maupun swasta yang berada di bawah Lembaga Kementerian Agama. Perpustakaan Madrasah Kota Banjarmasin ikut berjasa dalam menghasilkan lulusan yang berprestasi melalui perannya sebagai penyedia dan pengelola informasi. Hal tersebut tentunya tidak terlepas dari peran pustakawannya.

Berdasarkan hasil observasi sementara yang penulis lakukan pada Perpustakaan Madrasah Aliyah dan Tsanawiyah Negeri Kota Banjarmasin, bahwasanya tenaga perpustakaan atau pustakawan yang bekerja diperpustakaan madrasah tersebut tidak semuanya berlatar belakang pendidikan ilmu perpustakaan, dan sampai saat ini belum ada yang mengetahui memadai atau tidaknya kompetensi yang mereka miliki sebagai pustakawan sekolah.

\section{TINJAUAN PUSTAKA}

\section{A. PUSTAKAWAN SEKOLAH}

Kekayaan dan kualitas penyelenggaraan perpustakaan tergantung pada sumberdaya tenaga yang tersedia di dalam dan di luar perpustakaan sekolah. Karena alasan inilah, maka amatlah penting bagi perpustakaan sekolah memiliki tenaga berpendidikan serta bermotivasi tinggi, jumlahnya mencukupi sesuai dengan ukuran sekolah dan kebutuhan khusus sekolah menyangkut jasa perpustakaan. Pengertian "tenaga”, dalam konteks ini, adalah pustakawan dan asisten pustakawan berkualifikasi. Pustakawan sekolah hendaknya memiliki pendidikan profesional dan berkualifikasi, dengan pelatihan tambahan di bidang teori pendidikan dan metodologi pembelajaran.

Perpustakaan sekolah/madrasah memenuhi fungsinya dengan mengembangkan kebijakan danjasa, memilih dan memperoleh sumber daya informasi, menyediakan akses fisik danintelektual ke sumber informasi yang sesuai, menyediakan fasilitas pembelajaran, sertamempekerjakan staf terlatih. Secara terinci seseorang yang diberi tugas menjadi pustakawan sekolah harus memiliki sifat-sifat berikut (Bafadal, 1992) 1) memiliki pengetahuan di bidang perpustakaan sekolah; 2) suka bekerja, tekun, dan teliti dalam melaksanakan tugas-tugasnya; 3) harus terampil mengelola perpustakaan sekolah.

Keberadaan perpustakaan di sekolah/madrasah dapat berfungsi sesuai dengan tuntutan perundangundangan jika dikelola oleh pengelola perpustakaan, yang lazim disebut pustakawan dan/atau tenaga teknis perpustakaan. Dalam Undang Undang Perpustakaan No. 43 Tahun 2007 (2009: 18) pustakawan adalah "seseorang yang memiliki kompetensi yang diperoleh melalui pendidikan dan/atau pelatihan kepustakawanan serta mempunyai tugas dan tanggung jawab untuk melaksanakan pengelolaan dan pelayanan perpustakaan”. Dan dalam Pedoman Perpustakaan Sekolah IFLA/UNESCO (14) pustakawan sekolah adalah "tenaga kependidikan berkualifikasi serta profesional yang bertanggung jawab atas perencanaan dan pengelolaaan perpustakaan sekolah, didukung oleh tenaga yang mencukupi, bekerja sama dengan semua anggota komunitas sekolah dan berhubungan dengan perpustakaan umum dan lain-lainnya”.

Peran utama pustakawan ialah memberikan sumbangan pada misi dan tujuan sekolahtermasuk prosedur evaluasi dan mengembangkan serta melaksanakan misi dan tujuanperpustakaan sekolah. Dalam kerjasama dengan senior manajemen sekolah, administratordan guru, maka pustakawan ikut dalam pengembangan rencana dan implementasi kurikulum. Pustakawan memiliki pengetahuan dan keterampilan yang berkaitan dengan penyediaan informasi dan pemecahan masalah informasi serta keahlian dalam menggunakan berbagai sumber, baik tercetak maupun elektronik. Pengetahuan,keterampilan dan keahlian pustakawan sekolah mampu memenuhi kebutuhan masyarakatsekolah tertentu. Di samping itu, pustakawan sekolah hendaknya memimpin kampanye membacadan promosi bacaan anak, media dan budaya. 
Pustakawan sekolah hendaknya menciptakan suasana yang sesuai untuk hiburan dan pembelajaran yang bersifat menarik, ramah serta terbuka bagi siapa saja tanpa rasa takut dan curiga.Semua orang yang bekerja di perpustakaan sekolah harus memiliki reputasi yang baik dalam kaitannya dengan pengguna. Pustakawan sekolah diharapkan mampu melakukan tugas berikut (International Federation of Library Association (IFLA), 2006) 1) menganalisis sumber dan kebutuhan informasi komunitas sekolah; 2) memformulasi dan mengimplementasi kebijakan pengembangan jasa; 3) mengembangkan kebijakan dan sistim pengadaan sumberdaya perpustakaan; 4) mengkatalog dan mengklasifikasi materi perpustakaan; 5) melatih cara penggunaan perpustakaan; 6) melatih pengetahuan dan keterampilan informasi; 7) membantu murid dan guru mengenai penggunaan sumberdaya perpustakaan dan teknologi informasi; 8) menjawab pertanyaan referensi dan informasi dengan menggunakan berbagai materi yang tepat; 9) mempromosikan program membaca dan kegiatan budaya; 10) ikut serta dalam kegiatan perencanaan terkait dengan implementasi kurikulum; 11) ikut serta dalam persiapan, implementasi dan evaluasi aktivitas pembelajaran; 12) mempromosikan evaluasi jasa perpustakaan sebagai bagian dari sistem evaluasi sekolah secara menyeluruh; 13) membangun kemitraan dengan organisasi di luar sekolah; 14) merancang dan mengimplementasi anggaran; 15) mendesain perencanaan strategis; 16) mengelola dan melatih tenaga perpustakaan.

\section{B. KOMPETENSI PUSTAKAWAN SEKOLAH}

Dalam "Etika Kepustakawanan” Hermawan dan Zen (Hermawan \& Zen, 2006) menyebutkan bahwa dari Hasil Diskusi Komisi II Rapat Koordinasi Pengembangan Jabatan Fungsional Pustakawan dengan Pemerintah Provinsi, Kabupaten/Kota seluruh Indonesia yang diselenggarakan oleh Perpustakaan Nasional RI, merumuskan bahwa "Kompetensi secara umum adalah kemampuan, pengetahuan, dan keterampilan, sikap, nilai perilaku serta karakteristik pustakawan yang diperlukan untuk melaksanakan pekerjaan secara optimal”. Dengan demikian kompetensi adalah kemampuan untuk melaksanakan atau melakukan suatu pekerjaan atau tugas yang dilandasi atas ketrampilan, dan pengetahuan yang didukung oleh sikap kerja yang dituntut oleh pekerjaan tesebut.

Dalam Undang-Undang Perpustakaan No. 43 tahun 2007 (2009: 20) dikemukakan bahwa Tenaga Perpustakaan adalah 1) tenaga perpustakaan terdiri atas pustakawan dan tenaga teknis perpustakaan; 2) pustakawan sebagaimana dimaksud pada ayat (1) harus memenuhi kualifikasi sesuai dengan standard nasional perpustakaan; 3) tugas tenaga teknis perpustakaan sebagaimana dimaksud pada ayat (1) dapat dirangkap olelh pustakawan sesuai dengan kondisi perpustakaan yang bersangkutan; 4) ketentuan mengenai tugas, tanggung jawab, pengangkatan, pembinaan, promosi, pemindahan tugas, dan pemberhenian tenaga perpustakaan yang berstatus penawai negeri sipil dilakukan sesuai dengan peraturan perundang-undangan; 5) ketentuan mengenai tugas, tanggung jawab, pengangkatan, pembinaan, promosi, pemindahan tugas, dan pemberhentian tenaga perpustakaan yang berstatus non pegawai negeri sipil dilakukan sesuai dengan peraturan yang ditetapkan oleh penyelenggara perpustakaan yang bersangkutan.

Kualitas dan keterampilan mendasar yang diharapkan dari tenaga perpustakaan sekolah didefinisikan sebagai berikut (IFLA: 16) 1) kemampuan berkomunikasi secara positif dan terbuka dengan anak dan orangdewasa; 2) kemampuan memahami kebutuhan pengguna; 3) kemampuan bekerja sama dengan perorangan serta kelompok di dalam dan di luar komunitas sekolah; 4) memiliki pengetahuan dan pemahaman mengenai keanekaragaman budaya; 5) memiliki pengetahuan mengenai metodologi pembelajaran dan teori Pendidikan; 6) memiliki ketrampilan informasi serta bagaimana menggunakannya; 7) memiliki pengetahuan mengenai materi perpustakaan yang membentuk koleksi perpustakaan serta bagaimana mengaksesnya; 8) memiliki pengetahuan mengenai bacaan anak, media dan ke budayaan; 9) memiliki pengetahuan serta 
keterampilan di bidang manajemen dan pemasaran; 10) memiliki pengetahuan serta keterampilan di bidang teknologi informasi.

Sebagaimana telah ditetapkan dalam Standar Nasional Pendidikan (SNP), setiap satuan pendidikan (sekolah/ madrasah) wajib memiliki ruang perpustakaanuntuk menunjang proses pembelajaran yang teratur dan berkelanjutan. Oleh karena itu, dapat disimpulkan bahwa setiap satuan pendidikan, dalam hal ini sekolah/madrasah, wajib memiliki seorang tenaga perpustakaan yang memiliki kualifikasi yang dipersyaratkan selambat-lambatnya pada tahun 2013.Berdasarkan Peraturan Menteri Pendidikan Nasional Republik Indonesia Nomor 25 Tahun 2008 tentang Standar Tenaga Perpustakaan Sekolah/Madrasah berkenaan dengan kompetensi tenaga perpustakaan sekolah/madrasah meliputi dimensi kompetensi sebagai berikut 1) dimensi kompetensi manajerial; 2) dimensi kompetensi pengelolaan informasi; 3) dimensi kompetensi kependidikan; 4) dimensi kompetensi kepribadian; 5) dimensi kompetensi social; 6) dimensi kompetensi pengembangaan profesi.

\section{FAKTOR YANG MEMPENGARUHI KOMPETENSI}

Berkenaan dengan profesionalisme Koswara (Koswara, 1998) dalam tulisannya mengatakan bahwa "Ilmu pengetahuan dan keterampilan yang diperoleh seorang profesional diperoleh dari lembaga pendidikan profesional khusus dalam bidangnya”. Misalnya, dalam dunia kepustakawanan, dari pernyataan tersebut dapat diketahui penguasaan ilmu pengetahuan dan keterampilan tentang perpustakaan, dokumentasi dan informasi tidak bisa dipungkiri sangat didukung oleh pendidikan pustakawan yang bersangkutan. Contoh, pustakawan alumnus Ilmu Perpustakaan dan Informasi dan pustakawan alumnus Kejuruan Ilmu Pendidikan akan terlihat berbeda cara kerjanya di perpustakaan, karena pustakawan alumnus Ilmu Perpustakaan dan Informasi telah memiliki sejumlah pengalaman teoritis di bidang perpustakaan dan informasi, sedangkan pustakawan alumnus Kejuruan Ilmu Pendidikan tidak. Dari dua orang sarjana yang berasal dari alumnus suatu perguruan tinggi ini saja sudah terlihat bedanya dengan melihat kemampuan mereka dalam bersikap, berbuat dan mengambil keputusan dalam lingkungan kerja.

Institusi adalah instansi dimana pustakawan berkiprah dalam pengabdiannya. Setiap pimpinan instansi atau kepala perpustakaan harus mempunyai sifat-sifat diagnosis, artinya harus mampu memahami situasi lingkungan pekerjaannya, termasuk memahami keinginan para pustakawan untuk memajukan dirinya. Pembentukan kelompok-kelompok pustakawan menurut jenjang kepangkatannya merupakan tanggung jawab pimpinan/kepala perpustakaan dalam upaya peningkatan kompetensi pustakawan. Pembentukan kelompok-kelompok tersebut dengan surat keputusan kepala perpustakaan atas usulan para pejabat dimana pustakawan ditempatkan. Umpamanya di Perpustakaan Nasional RI usul pembentukan kelompok-kelompok pustakawan itu dilakukan oleh para kepala pusat, direktoral dan sebagainya. Di Badan Perpustakaan misalnya di usulkan oleh kepala-kepala bagian atau bidang.

Tugas kepala instansi/perpustakaan adalah mendorong, menyemangati, memberikan fasilitas dan sebagainya kepada para pustakawan, atau memperlakukan secara adil, bijaksana antara pejabat struktural dengan pejabat fungsional pustakawan. Disinilah perlu adanya kemampuan adaptasi dan kemampuan komunikasi bagi setiap pimpinan suatu pustakawan agar dapat mendayagunakan para pustakawan. Kalau perlu pimpinan memberikan anggaran khusus untuk pengembangan kompetensi pustakawan yang dikelola oleh pustakawan sendiri agar menjadi pustakawan yang mandiri.Bukankah Tenaga perpustakaan berhak atas penghasilan di atas kebutuhan hidup minimum dan jaminan kesejahteraan sosial; pembinaan karier sesuai dengan tuntutan pengembangan kualitas; dan kesempatan untuk menggunakan sarana, prasarana, dan fasilitas perpustakaan untuk menunjang kelancaran pelaksanaan tugas. 
Dan tidak hanya itu, mereka juga dituntut untuk berusaha meningkatkan dan mengembangkan kompetensinya secara terus-menerus melalui berbagai kegiatan seperti pelatihan, penelitian, seminar, kursus, banyak membaca dan sejenisnya yang sangat penting untuk meningkatkan kompetensi seseorang untuk menjadi lebih profesional dalam menjalankan tugasnya.

\section{METODE PENELITIAN}

Jenis penelitian skripsi yang penulis angkat adalah penelitian lapangan (field research), yaitu penelitian dilakukan dengan terjun ke lapangan untuk menggali, menghimpun dan mengumpulkan sejumlah data yang diperlukan mengenai Kompetensi pustakawan sekolah di Perpustakaan Madrasah Aliyah dan Tsanawiyah Negeri kota Banjarmasin. Pendekatan dalam penelitian ini adalah pendekatan kualitatif, yaitu suatu pendekatan yang lebih menekankan analisanya pada proses pengumpulan deduktif dan induktif serta pada analisa terhadap dinamika hubungan antar fenomena yang diamati dengan menggunakan logika ilmiah. Dalam penelitian ini dilakukan beberapa tahap mengumpulkan data, meliputi observasi,wawancara dan dokumentasi. Sedangkan untuk analisis data mengacu pada analisis kualitatif yaitu dengan reduksi data, penyajian data, triangulasi, penarikan kesimpulan.

\section{HASIL DAN PEMBAHASAN}

\section{A. KOMPETENSI PUSTAKAWAN}

\section{Kompetensi manajerial}

Seorang pustakawan dituntut untuk memiliki ketrampilan administrasi/manajemen. Ketrampilan ini sangat berguna untuk mengatur semua tugas terkait dengan tugas kepustakawan maupun mengatur diri pustakawan tersebut dalam aktifitas sehari-hari. Sebagai seorang pustakawan, tentunya selalu berurusan dengan kegiatan pokoknya yaitu bekerja di perpustakaan dan selalu berhubungan dengan orang lain. Kemampuan manajerial menuntut pustakawan tidak hanya rapi menjalankan tugas administratif, namun juga mengembangkan visi dan misi pengelolaan dan pengembangan perpustakaan yang dikelolanya (Yusuf dkk., 2016).

Temuan penelitian menunjukkan bahwa para informan sudah merasa menjalankan kompetensi manajerial dengan baik, yakni dengan melakukan pengembangan secara rutin dalam tempo satu tahun atau enam bulan. Namun perlu ditekankan pula bahwa para informan belum menjelaskan gambaran upaya-upaya personal yang spesifik dalam kaitannya meningkatkan taraf kemanfaatan perpustakaan bagi pengguna. Seperti yang di ungkapkan informan sebagai berikut: "kita sebagai pustakawan memang mempunyai keinginan untuk memajukan perpustakaan dengan merencanakan program pengembangan koleksi, sarana dan prasarana juga menambah tenaga pustakawan, namun tidak semua berjalan dengan lancar karena terhalang anggaran dan sebagainya. Klasifikasi dilakukan apabila ada koleksi buku baru dan juga membuatkan katalog buku tersebut” (hasil wawancara dengan responden N Pustakawan MTsN Pemurus Dalam).

Sama halnya dengan yang diungkapkan Responden WA Pustakawan MTsN 1 Pekauman. "Saya disini setiap tahunnya merencanakan penambahan pustakawan begitu juga dengan sarana yang ada sekarang, koleksi setiap tahun dilakukan evaluasi untuk mengetahui keterpakaian bahan koleksi, koleksi sudah terklasifikasi namun katalog baru beberapa buku kalau masalah anggaran itu tergantung kebijakan sekolah”.

Program perpustakaan tidak bisa direalisasikan karena dana yang diharapkan tidak dapat turun (cair), hal ini tentu menjadi dilema besar bagi pustakawan. Artinya proses penilaian kebutuhan (needs assessment) perpustakaan harus diselaraskan dengan kebutuhan sekolah. "Setiap tahun dilakukan evaluasi terhadap perencanaan yang dilakukan seperti pengembangan koleksi, penambahan sarana mengadakan promosi, data pengunjung setiap semester dilakukan evaluasi 
karena itu sangat penting dengan begitu kita dapat mengetahui jumlah pengunjung perpustakaan kita. Katalogisasi kita lakukan juga klasifikasi dengan menggunakan buku Towa. Penambahan pustakawan sepertinya sulit karena anggaran yang tidak memadai” (hasil wawancara dengan responden FH Pustakawan MTsN 3 Mulawarman).

Tugas perencanaan dalam fungsi manajerial sangat penting kiranya dalam kaitannya dengan pengembangan fungsi dan manfaat perpustakaan sekolah. Fungsi perencanaan ini seharusnya mencakup rencana-rencana untuk pengembangan koleksi, sarana dan prasarana, pengembangan SDM tenaga perpustakaan, rancangan anggaran anggaran sampai dengan perencanaan program promosi perpustakaan.. Hal tersebut berimbas pada pola perencanaan yang lebih sistematis, pada umumnya perencanaan pengembangan perpustakaan dilakukan setahun sekali, hal ini disusun sesuai dengan rancangan anggaran tahunan sekolah. Seperti diungkapkan responden responden EM Pustakawan MAN 2 Model Bnjarmasin. "Kita merencanakan program yang dapat meningkatkan minat pengunjung perpustakaan untuk berkunjung keperpustakaan, semua program akan dievaluasi untuk mengetahui keterlaksanaannya, visi dan misi perpustakaan juga ikut dievaluasi, anggaran sendiri memang ada dari sekolah."

Sangat berbeda dengan ungkapan responden H Pustakawan MAN 3 Mulawarman. "Perencanaan penambahan koleksi, penambahan sarana juga penambahan pustakawan kita lakukan, namun kita kembalikan ke sekolah yang bisa menentukan terlaksananya atau tidak perencanaan tersebut”.

Namun tidak dapat dipungkiri bahwa fenomena perpustakaan sekolah yang dikaji dalam penelitian ini belum sepenuhnya mampu memfasilitasi pengguna melalui sarana dan prasarana fisiknya. Hal ini ditemukan dari hasil amatan peneliti sewaktu melakukan kunjungan dan wawancara. Pemenuhan fasilitas fisik seperti meja, kursi dan komputer masih menjadi prioritas utama dalam pengembangan sarana perpustakaan sekolah.

Hasil dan pembahasan berisi hasil-hasil temuan penelitian dan pembahasannya. Tuliskan temuantemuan yang diperoleh dari hasil-hasil penelitian yang telah dilakukan dan harus ditunjang oleh data-data yang memadai. Hasil-hasil penelitian dan temuan harus bisa menjawab pertanyaan atau hipotesis penelitian di bagian pendahuluan.

\section{Kompetensi pengelolaan informasi}

Seorang pustakawan sebagai seseorang yang berperan mengelola pengetahuan tentunya idealnya juga memiliki pengetahuan yang memadai. Hal ini sangat penting ketika seorang pustakawan dihadapkan pada tugas-tugas pengelolaan informasi. Kompetensi ini menekankan pada kualitas pengetahuan dan pemahaman pustakawan, tidak melulu pada tugas administratif teknis. Penguasaan pengetahuan sangat diperlukan ketika seorang pustakawan berhadapan dengan tugas pengelompokan, merangkai dan mengelola literatur yang dimiliki. Hasil penelitian ini ternyata mendapati bahwa para responden masih memiliki banyak keterbatasan pengetahuan dan pemahaman sebagai mana dibutuhkan seorang pustakawan yang berkompeten. Sesuai aturan yang berlaku yaitu Peraturan Menteri Pendidikan Nasional Republik Indonesia Nomor 25 TAHUN 2008.

Hal yang banyak dipahami pustakawan adalah pengetahuan tentang judul buku/literatur yang ada di dalam perpustakaan, tanpa memahami atau pernah membaca. Hal ini muncul ketika peneliti mengeksplorasi pengetahuan dan pemahaman personal pustakawan di luar konteks administratif. Hal yang disoroti pustakawan terkait pengelolaan informasi yakni lebih pada penggunaan teknik atau metode khusus dalam mengelompokkan atau menata koleksi perpustakaan. Hal ini mengarah pada penggunaan piranti lunak. Walaupun pemberdayaan teknologi informasi juga belum sepenuhnya maksimal, seperti diungkapkan responden EM, yakni: “inventarisasi, klasifikasi 
sesuai DDC, Sedangkan untuk perawatan bahan pustaka masih menggunakan cara yang manual belum sampai pada pemanfaatan teknologi informasi". "menggunakan alat bantu seleksi dalam pemilihan bahan pustaka kemudian dikoordinasikan dengan guru dan kepala sekolah. Perawatan bahan pustaka masih manual belum ada yang didigitalkan, juga belum ada layanan internet diperpustakaan ini” (hasil wawancara dengan N pustakawan MTsN Pemurus).

Bahkan responden $\mathrm{H}$ mengatakan bahwa pemanfaatan teknologi informasi belum dibutuhkan diperpustakaan sekolah Menengah Akhir. "Belum ada fasilitas komputer apalagi internet karena takut dimanfaatkan dengan hal yang tidak baik oleh pengguna perpustakaan, kalau koleksi kita sesuaikan dengan kurikulum yang ada”.

Perpustakaan sekolah menyediakan informasi dan ide yang merupakan dasar keberhasilan fungsional dalam masyarakat masa kini yang berbasis pengetahuan dan informasi. Perpustakaan sekolah membekali murid berupa keterampilan pembelajaran sepanjang hayat serta imajinasi, memungkinkan mereka hidup sebagai warganegara yang bertanggung jawab. Seperti yang diungkapkan responden FH yaitu: "perpustakaan sebagai penyedia informasi sudah sepantasnya kita sebagai pustakawan yang bekerja diperpustakaan tersebut mengelola informasi dengan baik, seperti melakukan inventarisasi, katalogisasi, menyeleksi bahan koleksi yang sesuia kebutuhan dan kurikulum yang ada, fasilitas teknologi informasi memang belum terlaksana namun sebisa mungkin akan diadakan dalam waktu dekat ini”.

Berbeda dengan yang di ungkapkan responden WA: "perpustakaan sekolah itu sepertinya hanya sebagai pelengkap sekolah, karenanya koleksi yang disediakan disesuaikan dengan kurikulum yang ada dan tidak begitu dipentingkan perawatannya."

Apabila mengacu pada ketentuan tentang kompetensi pustakawan, maka seharusnya pustakawan bisa melakukan analisis kebutuhan pemanfaatan teknologi informasi, menerapkan teknologi dan membimbing pengguna perpustakaan dalam pemanfaatan teknologi informasi (TIK) dalam memfasilitasi proses belajar mengajar. Hasil penelitian ini menggambarkan bahwa pustakawan belum berhasil dengan baik dalam menerapkan dan membimbing pengguna perpustakaan.

\section{Kompetensi kependidikan}

Kompetensi wawasan kependidikan mutlak dimiliki setiap insan yang bergerak di bidang pendidikan. Pustakawan idealnya memahami tujuan dan fungsi sekolah/madrasah dalam konteks pendidikan nasional, peran perpustakaan sebagai sumber belajar sekaligus mampu memfasilitasi peserta didik untuk belajar mandiri. Temuan penelitian ini sudah mampu memberikan gambaran positif, yakni pustakawan mampu menyelaraskan program dan peran perpustakaan untuk mendorong proses pendidikan yang berlangsung di sekolah.

Hal tersebut berkaitan juga dengan sikap hati-hati pustakawan dalam menghadapi perkembangan teknologi informasi, salah satunya dengan mempertimbangkan ulang keterbukaan akses internet bagi pengguna perpustakaan yang dirasa tidak bersesuaian dengan tujuan pendidikan. Kontradiksi kembali muncul disini, yakni ketika pustakawan belum berhasil menjalin irama antara kebutuhan akan informasi dari internet dengan resiko informasi negatif bagi pengguna perpustakaan. Temuan penelitian ini justru menggambarkan bagaimana para responden lebih bersikukuh untuk mempertahankan prinsip-prinsip pendidikan dan berupaya mengurangi resiko-resiko yang dapat dimunculkan. "Belum ada fasilitas komputer apalagi internet karena takut dimanfaatkan dengan hal yang tidak baik oleh pengguna perpustakaan” (hasil wawancara dengan responden $\mathrm{H}$ Pustakawan MAN 3 Mulawarman). 
Unsur kompetensi kependidikan tertuang dalam pemahaman pustakawan terhadap visi dan misi pendidikan (di sekolah terkait) dan menyelaraskannya dengan program-program perpustakaan. Menempatkan perpustakaan sebagai sumber informasi siswa maupun guru dalam belajar dan secara konsisten mempertahankan tujuan tersebut. Sebagaimana yang di ungkapkan responden FH yaitu: “...Seperti yang pernah kita ketahui bahwa perpustakaan sekolah itu adalah pusat sumber belajar siswa dan sebagai pustakawan kita berusaha agar tujuan tersebut tercapai...”.

Hal serupa juga diungkapkan respoben EM: "visi dan misi perpustakaan ditentukan oleh sekolah menyelaraskan dengan visi dan misi sekolah namun tetap berdasarkan usukan perpustakaan". Responden di kesempatan berbeda menekankan bahwa pihak sekolah (melalui kepala sekolah) selalu menekankan pentingnya harmoni antara proses pembelajaran dengan peran perpustakaan sebagai pendukung proses belajar, oleh sebab itu pelaksanaan program perpustakaan terkait erat dengan kebijakan sekolah. "Program literasi informasi dalam program kerja dilakukan bersamaan dengan bimbingan pemakai yaitu pada awal tahun ajaran baru dengan didukung oleh pihak sekolah” (hasil wawancara dengan WA Pustakawan MTsN Pekauman).

Namun demikian pemenuhan kompetensi literasi yang mengharapkan pustakawan untuk kreatif dan produktif dalam menulis karya ilmiah belum bisa terbangun secara sempurna. Tentunya kendala ini tidak hanya terjadi pada tingkatan pustakawan, baik guru maupun dosen seringkali juga masih kesulitan untuk produktif dalam menyusun karya tulis ilmiah. Pada titik ini optimisme akan kompetensi literasi informasi dapat dibangun, dengan berdasar pada kemampuan dan kemauan pustakawan untuk mendokumentasikan pengetahuannya.

\section{Kompetensi kepribadian}

Kompetensi kepribadian yakni integritas dan etos kerja yang tinggi. Integritas diwujudkan dalam perilaku disiplin, bersih, dan rapi, jujur dan adil serta sikap sopan, santun, sabar dan ramah. Meninjau pada pendekatan penelitian, luasnya variasi kompetensi kepribadian menyulitkan peneliti untuk melakukan pengamatan secara mendetail, termasuk dalam mengajukan pertanyaan tentang aspek-aspek personal tersebut. Peneliti dalam hal ini mengambil gambaran besar dari cara pandang responden (pustakawan) terhadap kerja yang dilakukan dan kinerja yang diwujudkan. Salah seorang responden, yakni FH menyatakan fokus pikirannya kepada laporan pertanggung jawaban sebagai wujud integritasnya dalam bekerja; "setiap program yang kita rencanakan akan ada evaluasi dan setiap kegiatan yang dilakukan perpustakaan akan kita lakukan laporan, laporan dilakukan sesuai dengan kebutuhan yang ada”. Senada dengan yang diungkapkan responden EM Pustakawan MAN 2 Model: “...bentuk tanggung jawab kita dalah membuat laporan atas semua kegiatan yang kita lakukan...”.

Responden dalam tahap ini cukup kesulitan memberikan jawaban definitif dan terperinci tentang laporan pertanggung jawaban, dan justru memberikan gambaran seperti apa laporan yang harus disusunnya. Terkait dengan aspek-aspek subjektif dalam bekerja, responden merasa sudah berupaya semaksimal mungkin untuk mewujudkan sikap rapi, jujur, adil, sopan dan sebagainya. Dengan penekanan apabila terjadi kesalahan, maka hal itu perlu dimaklumi. Terkait dengan etos kerja, responden WA menyoroti perlunya sikap; “...tidak memutuskan segala sesuatu dengan sendiri tetap meminta saran dan mengkoordinasikannya dengan atasan”. "Apapun yang akan dilakukan perpustakaan kita koordinasikan dengan kepala sekolah karena semua keputusan ada padanya" (hasil wawancara dengan pustakawan $\mathrm{H}$ ).

Adapun yang diungkapkan responden N Pustakawan MTsN Pemurus: "setiap ada program perpustakaan yang dijalankan pasti akan diminta laporannya oleh pihak sekolah, kita sebagai tanggung jawab kita”. 
Berdasarkan penyataan tersebut dapat ditarik analogi bahwa pemahaman tentang integritas masih terpaku pada sifat-sifat tugas administratif dalam bentuk pelaporan kepada sekolah. Temuan ini bisa menjadi dasar asumsi bahwa penekanan tugas administratif masih menjadi pendekatan yang populer di kalangan pustakawan.

\section{Kompetensi sosial}

Terkait dengan hubungan sosial, para responden menyebutkan pentingnya kerjasama dan hubungan baik dengan pihak lain yang berkontribusi besar terhadap berlangsungnya program perpustakaan, seperti sesama pustakawan, kepala sekolah, guru mata pelajaran ataupun organisasi profesi. Hal ini diungkapkan oleh responden EM dan FH, sebagai berikut: "bekerjasama merupakan salah satu upaya yang kita lakukan untuk perkembangan perpustakaan kita misalkan kita mau mengadakan koleksi baru maka kita minta guru dan karyawan lain untuk ikut dalam pemilihan koleksi baru tersebut” (hasil Wawancara dengan pustakawan EM). “...Guru dan murid kita ikut sertakan dalam mengambil keputusan untuk pengembangan koleksi dan sarana prasarana yang dibutuhkan..” (hasil Wawancara dengan pustakawan FH ).

Organisasi profesi dipandang memiliki peran penting untuk turut mengembangkan kemampuan dan kompetensi pustakawan, terutama untuk berbagi pengetahuan dan skill antar pustakawan. Menariknya dalam t emuan penelitian, para responden kurang begitu mengungkapkan perhatian terhadap pembangunan karakter pribadi dan pola hubungan dengan pemustaka, dalam hal ini siswa. Yang mana seharusnya mendapatkan perhatian lebih dari para pustakawan. Terkait dengan kompetensi pribadi, fungsi komunikasi dan ketrampilan didalamnya sangatlah penting, terutama dalam menjalin pemahaman terhadap pemustaka demi tercapainya kepuasan pemustaka terhadap layanan perpustakaan. “...ikut berorganisasi kepustakawanan merupakan hal penting dimana kita bisa bertukar pikiran untuk kemajuan perpustakaan” (hasil wawancara dengan pustakawan $\mathrm{H}$ ). Berbeda dengan ungkapan responden $\mathrm{N}$ : "perpustakaan sekolah pentingnya ya bekerjasama dengan sekolah karena semua keputusan yang ada diperpustakaan ditentukan oleh sekolah”.

Lima hal yang layaknya dikedepankan pustakawan adalah kemampuan untuk memperhatikan, yakni mampu berkomunikasi dengan kehadiran pemustaka; mendengarkan yakni mampu mendengar dan menganalisa dengan cepat apa yang dibutuhkan pemustaka; mengamati, mampu meneliti pembicaraan; mampu mengklarifikasi komunikasi yang dianggap kurang tepat serta mampu memberi tanggapan yang tepat. Kelima hal tersebut apabila diimplementasikan dalam interaksi sehari-hari pustakawan tentu sangat menunjang tercapainya etos kerja yang tinggi. Peneliti menilai fenomena ini berkaitan dengan belum berkembangnya kesadaran pemustakan akan penilaian kinerja secara personal, sehingga fokus utama pustakawan dalam melayani pemustaka seringkali tergeser ke dalam hubungan struktural dan administratif. Sebagaimana ungkapan dari responden WA: "perpustakaan tidak akan maju tanpa dorongan dari sekolah tempat perpustakaan tersebut berdiri, perpustakaan memerlukan perhatian dari sekolah dan guru yang ada disekolah tersebut, kerjasama yang dijalin perpustakaan seperti guru yang memberikan sebuah tugas kesiswanya dan siswa tersebut dipersilahkan keperpustakaan untuk mengerjakannya, sehingga perpustakaan akan ada minat siswa untu berkunjung keperpustakaan."

\section{Kompetensi pengembangan profesi}

Standar kompetensi pengembangan profesi bagi pustakawan antara lain tertuang dalam pembuatan karya tulis, meresensi buku, menyusun indeks. Bibliografi, abstrak dan menyusun pedoman dan petunjuk teknis di bidang ilmu perpustakaan dan informasi. Temuan penelitian ternyata belum bisa menggambarkan kompetensi pengembangan profesi yang memadai. Kesemua responden mengaku selama bekerja kesulitan untuk menyusun karya ilmiah berdasarkan hasil kajiannya sendiri, yang 
memang dilaksanakan dengan pendekatan ilmiah. Demikian halnya dengan resensi buku dan abstrak. Para responden menjelaskan bahwa keterbatasan waktu dan sumber daya menyulitkan pustakawan untuk secara khusus melakukan sebuah kajian ilmiah di tempat kerjanya.

Hasil penelitian ini juga berhasil mengungkap perspektif pustakawan terhadap apa yang disebut dengan pengembangan profesi, yang mana menitikberatkan pada kegiatan pelatihan ataupun seminar tentang pustakawan dan ilmu perpustakaan serta keterlibatan dalam organisasi profesi yang diharapkan dapat meningkatkan kompetensi. Hal tersebut kembali lagi mengungkapkan pemahaman bahwa tugas dan peran administratif merupakan kunci utama dalam peningkatan kompetensi, peran bahkan kinerja pustakawan. Seperti diungkap responden FH sebagai berikut; "mengikuti seminar dan pelatihan merupakan upaya yang saya lakukan untuk meningkatkan kompetensi, selain itu sebagai anggota organisasi profesi pustakawan.”

Senada dengan yang disampaikan oleh responden $\mathrm{H}$, “ikut dalam organisasi kepustakawanan, mengikuti seminar juga pelatihan yang diadakan oleh lembaga perpustakaan atau yang terkait”. Hampir semua responden mengungkapkan pernyataan yang sama bahwa berorganisasi dan mengikuti seminar serta pelatihan tentang kepustakawanan merupakan bentuk aprisiasi mereka terhadap profesi mereka.

Mengacu pada aturan undangan-undang tentang perpustakaan, betul adanya bahwa pelatihan merupakan salah satu teknik atau metode utama yang harus dilakukan untuk membentuk dan meningkatkan kompetensi pustakawan. Melalui pelatihan, diharapkan pustakawan dapat memperluas pengetahuan, ketrampilan dan kompetensinya mengacu pada standar yang sudah ditetapkan. Apabila meninjau temuan penelitian, dapat ditarik pemahaman bahwa para pustakawan mengharapkan peran asosiasi profesi dalam menyelenggarakan pelatihan sebagai pihak yang dianggap paling memahami dan mengetahui kebutuhan kompetensi pustakawan.

\section{B. FAKTOR-FAKTOR YANG MEMPENGARUHI KOMPETENSI}

Kompetensi pustakawan tentu tidak muncul dengan sendirinya, selain perlunya materi yang tertuang dalam pendidikan dan pelatihan, seorang pustakawan dalam mengembangkan kompetensi tidak dapat melepaskan diri dari pengaruh faktor-faktor lain. Hasil penelitian ini memunculkan tiga (3) faktor utama yang dianggap memiliki kontribusi terhadap taraf kompetensi perpustakaan, yakni faktor pendidikan pustakawan, faktor institusi (sekolah) dan intensitas mengikuti kegiatan pengembangan profesi.

Ketiga faktor utama tersebut muncul dari hasil wawancara dengan responden maupun hasil amatan peneliti. Sebagaimana yang dijelaskan oleh responden EM yaitu: "kita sebagai pustakawan tentunya berupaya sendiri untuk meningkatkan kompetensi yang kita miliki seperti seringnya mengikuti seminar dan pelatihan, namun juga tidak akan bisa berjalan dengan lancar apabila tanpa dukungan dari atasan tempat kita bekerja”.

Sama halnya dengan pernyataan FH Pustakawan MTsN 3 Mulawarman: "pernah ada keinginan untuk melanjutkan pendidikan kejenjang yang lebih tinggi namun karena baru diterima kerja sehingga izin tidak keluar”.

Penelitian ini juga menemukan peran faktor ekstrinsik yang melandasi berkembangnya motivasi pustakawan. Sumber motivasi utama yang dirasakan pustakawan yakni berasal dari pimpinan, seperti kepala sekolah serta situasi lingkungan kerja yang dianggap positif, terutamanya hubunga dengan sesama pustakawan. Responden $\mathrm{N}$ dan $\mathrm{H}$ menjelaskan bahwa adanya hubungan baik dan kerjasama menyebabkan suasana kerja menyenangkan dan mendukung bagi pengembangan kompetensi. "motivasi akan muncul apabila dari pihak sekolah memberikan dukungan terhadap 
kita, misalkan apabila ada pertemuan pustakawan dan seminar kita difasilitasi”. “Kepala sekolah sangat berperan dalam pengembangan kompetensi kita, kalau ada seminar kita di ikut sertakan dan difasilitasi, namun apabila sebaliknya maka kita tidak akan bisa berkembang"(hasil wawancara dengan responden WA Pustakawan MTsN Pekauman).

Berdasarkan uraian hasil penelitian di atas, maka dapat disimpulkan bahwa terdapat tiga faktor besar yang berkaitan atau mempengaruhi pencapaian kompetensi pustakawan sekolah, yakni faktor internal yang berbasis pada motivasi, faktor institusi yang mengarah pada kebijakan sekolah dan faktor intensitas mengikuti pelatihan atau seminar.

\section{KESIMPULAN}

Secara umum dapat disimpulkan bahwa pencapaian pustakawan perpustakaan sekolah belum sepenuhnya dapat menunjukkan kompetensi mereka. Khususnya kompetensi pengembangan profesi, kompetensi pengelolaan informasi dan kompetensi kepribadian dan sosial. Hasil penelitian ini memunculkan tiga (3) faktor utama yang dianggap memiliki kontribusi terhadap taraf kompetensi pustakawan yakni 1) faktor individual pustakawan, penelitian ini berhasil mengidentifikasikan faktor personal berdasar hasil wawancara dengan responden. Faktor utama yang dikedepankan oleh responden adalah faktor motivasi, yang terbentuk dari nilai internal dan juga dukungan dari orang-orang disekitar pustkawan; 2) faktor institusi (sekolah), kebijakan sekolah sebagai institusi melalui kepala sekolah dipahami berperan besar dalam mengembangkan kompetensi para pustakawan. Hal ini mengingat anggaran perpustakaan sekolah berada di bawah rencana anggaran sekolah, sehingga secara otomatis perpustakaan sekolah bergantung pada bagaimana pengurus sekolah mengatur kebijakan dan anggaran; 3) faktor intensitas dalam mengikuti seminar dan pelatihan, mengikuti seminar dan pelatihan masih menjadi tradisi yang seharusnya dilakukan oleh pustakawan dalam upaya meningkatkan kompetensi.

\section{DAFTAR PUSTAKA}

Arikunto, Suharsimi. Manajemen Penelitian. Jakarta: Rineka Cipta, 2002.

Arikunto, Suharsimi. Prosedur Penelitian Suatu Pendekatan Praktek Jakarta: Asdi Mahasatya, 2006.

Bafadal, I. (1992). Pengelolaan perpustakaan sekolah. Bumi Aksara.

Bungin, Burhan. Analisis data penelitian kualitatif. Jakarta : Raja Grafindo Persada, 2007.

Faisal, Sanapiah. Format-Format Penelitian Sosial. Jakarta: Raja Grafindo Perada.2007.

Hermawan, R., \& Zen, Z. (2006). Etika kepustakawanan: Suatu pendekatan terhadap kode etik pustakawan Indonesia. Sagung Seto.

Indonesia. Undang-Undang RI Nomor 43 Tahun 2007 Tentang Perpustakaan. Jakarta: Tamita Utama, 2009.

International Federation of Library Association (IFLA). (2006). School Library Guidelines. International Federation of Library Association (IFLA. https://archive.ifla.org/VII/s11/pubs/SchoolLibraryGuidelines-id.pdf

Koswara, E. (1998). Dinamika informasi dalam era global.

Lasa Hs, Manajemen Perpustakaan Sekolah. Yogyakarta: Pinus, 2009.

Makarim, Luthfiati. Menjadi Pustakawan: Memaknai Hidup. Dalam Seminar Kompetensi

Pustakawan: Pandangan Lembaga Pendidikan, Lembaga Perpustakaan dan

Pustakawan, 2008. 
Pendit, Putu Laxman. Penelitian Ilmu perpustakaan dan Informasi: suatu pengantar epistimologi dan metodologi. Jakarta: JIP-FSUI, 2003.

Pawit M. Yusuf dan Yaya Suhendar. Pedoman Penyelenggaraan Perpustakaan Sekolah. Jakarta: Kencana, 2007.

Peraturan Menteri Pendidikan Nasional Republik Indonesia No. 25 Tahun 2008 Tentang Standar Tenaga Perpustakaan Sekolah/Madrasah

Poerwandari, E. Kristi. Pendekatan Kualitatif dalam Penelitian Psikologi. Jakarta: Lembaga Pengembangan Sarana Pengukuran dan Pendidikan Psikologi (LPSP3) Fakultas Psikologi UI, 1998.

Sugiyono, Metode Penelitian Pendidikan: Pendekatan Kuantitatif, Kualitatif, Dan R\&D, (Bandung: Alfabeta, 2012).

Suherman. Perpustakaan Sebagai Jantung Sekolah: referensi pengelolaan perpustakaan sekolah. Bandung: MQS Publishing dan Saga Visi Paripurna, 2009.

Sulistyo-Basuki. Kode Etik dan Organisasi Profesi. Dalam Apresiasi Kepustakawanan PD-IPI Jakarta Periode 1999 - 2003. Jakarta: Ikatan Pustakawan Indonesia. 2003.

Yusuf, P. M., Suhendar, Y., \& Yusuf, P. M. (2016). Pedoman penyelenggaraan perpustakaan sekolah. Kencana Prenada Media Group, 2010. 